\title{
口蓋形成におけるロ蓋垂縫合法の一考案
}

\author{
深谷昌彦・佐藤弘喜・伊藤義澄・倉内 剛
}

\section{An idea on the uvula suturing technic in palatoplasty}

\author{
Masahiko Fukaya, Hiroki Satoh, Yoshizumi Ito \\ Tsuyoshi Kurauchi
}

1. はじめに

口蓋裂言語の正常化には，口腔内圧．鼻咽腔閉鎖機能 の回復が必要であり， 口蓋㚏後方移動による形態的鼻咽 腔の縮少, 運動機能の保持が口蓋形成手術の必須条件之 なってくる， 口蓋垂筋は，かなり著明な運動を有する筋 であり， 口蓋帆挙筋と共に挙上されたとき鼻咽腔閉鎖に 関与する. しかし，口蓋垂の形成は粘膜のうすいことや， 筋層の発達に個人差が著しいこと，などから口蓋形成手 術中最もむずかしい部分の一つである.

私達は今回，口蓋垂形成の一つの試みとして鼻空側粘 膜の縫合後，口蓋垂先端を咽頭後壁に仮縫合し，口蓋垂 の形態を回復する方法を試みたので報告する。

本法は,

1. 口蓋垂先端を咽頭後壁に仮縫合することによって, 口蓋并の後方移動の可能範囲を確認することができる.

2. 口蓋升が緊張するため, 口蓋垂粘膜を均等な位置 で把握でき，さらに，口蓋垂頸部を筋縫合することなど によって，好ましい形態を作ることができる，などの利 点を見出した.

\section{2. 手術方法}

まず通法により，口蓋弁，鼻腔粘膜を剝離し，硬口蓋 後緑および大口蓋孔周辺を鈍的に槑離し, 後方移動の可 能性を確認したうえで，番腔粘膜を縫合する（図 1)

鼻腔粘膜縫合後, 口蓋垂先端を咽頭後壁に仮縫合する. (図 2,3)

仮縫合が容易であれば後方移動が充分行われる可能性 を意味する．軟口蓋部の口蓋側粘膜および口蓋升の内側 はやや緊張するため, 左右粘膜を均等に縫合することが でき, 軟口蓋部の三層縫合を容易にするため， 口蓋垂筋 の形態を整えることができる.

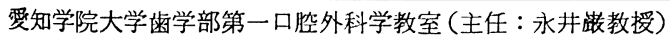
First Department of Oral Surgery, School of Dentistry Aichi-Gakuin University (Chief : Prof. Iwao Nagai) 受付 昭和 46 年 8 月 17 日

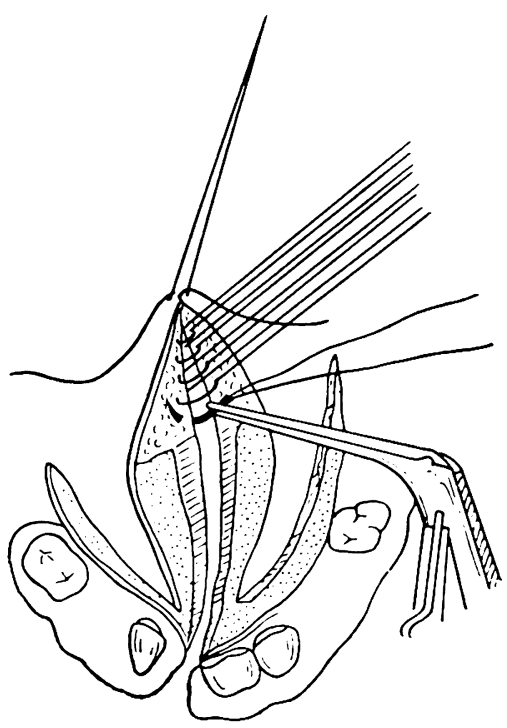

図 1

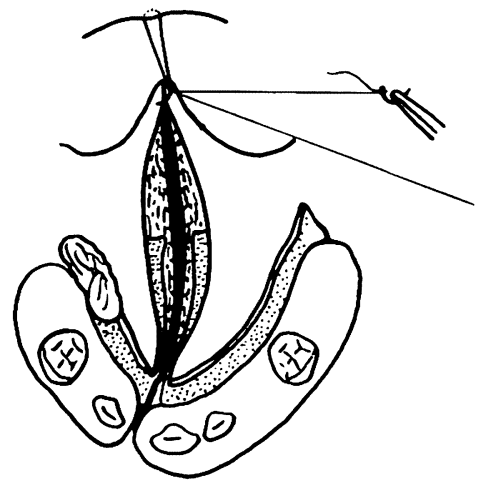

図 2

口蓋升を更に後方に移動しながら縫合することが容易 で, 縫合後は図 4 のごとく， 口蓋垂をよく举上した形態 に形成しらる．挙上された重は数日にして，鼻陧側粘膜 


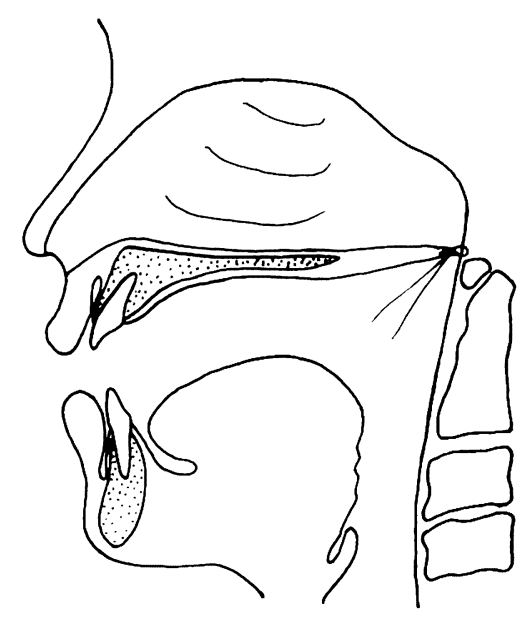

図3

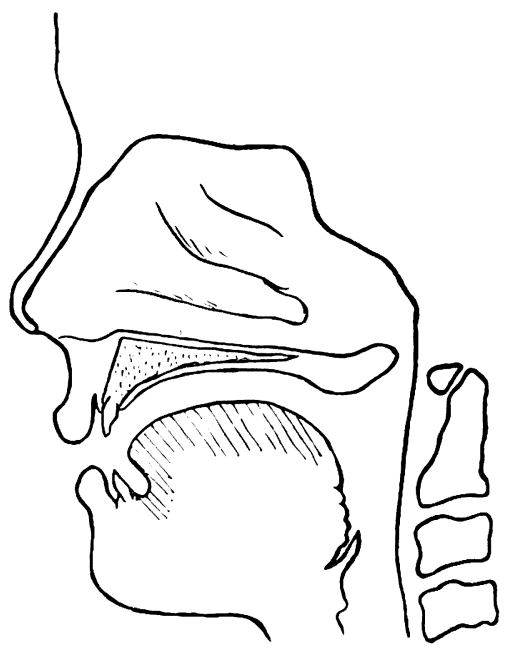

図 4

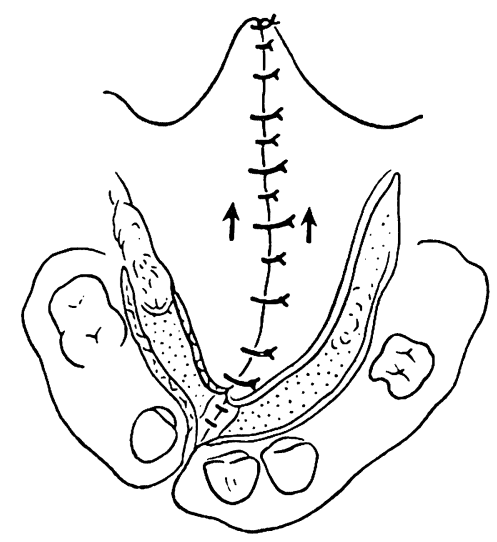

図 5

の後方へののびにより正常位に戻ってくる.（図 4,5)

\section{3. ま め}

今回私達が試みた口蓋垂縫合法は，仮縫合により口蓋 垂の形態を整えることが容易かつ確実で，しかも口蓋井 を更に後方へ送り込みながら縫合できるので, 機能的予 後も良好である。これまでに, 10 数例の手術に試みて， いずれも良い結果を得た。

本論交要旨は第六回日本形成外科学会中部地方会に発表した

\section{文献}

大森清一, 他: 形成外科学. 南山堂, 東京, p. 477. 昭 43 鬼塚卓弥: 形成外科手術费. 南江堂, 東京, p. 525. 炤 44, 永井 落：口唇裂・口蓋裂の手術手技について（3)，歯界 展望 $30: 517$ 昭 42 .

永井 蔽：口唇裂口蓋裂の手術手技について（4)，歯界展 望 $30: 683$ 昭 42 .

永井 政: 鬼唇及び口蓋裂の形成手術の実際. 外科治療 13 : 660 昭 40 .

Convers : Reconstructive Plastic Surgery. W. B. Saunders Co, 1968, p. 1416. 